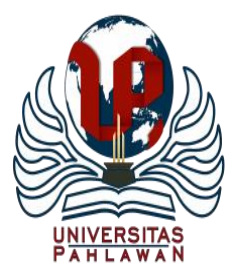

Jurnal Abdidas Volume 2 Nomor 4 Tahun 2021 Halaman 809-820

JURNAL ABDIDAS

http://abdidas.org/index.php/abdidas

\title{
Kemandirian Ekonomi Santri Pondok Pesantren Menghadapi Masa Pandemi
}

\author{
Nur Kholis ${ }^{1 凶}$, Ida Ayu Kade Rachmawati ${ }^{2}$, Hestin Muthmainah ${ }^{3}$, Rosita ${ }^{4}$ \\ Akuntansi, Sekolah Tinggi Ilmu Ekonomi Surakarta, Indonesia ${ }^{1,4}$ \\ Manajemen, Sekolah Tinggi Ilmu Ekonomi Surakarta, Indonesia ${ }^{2,3}$ \\ E-mail: nukonurkholis1988@gmail.com ${ }^{1}$, kade.rachmawati@gmail.com ${ }^{2}$, hestin.mutmainah7@ gmail.com ${ }^{3}$, \\ rositasetiawan@gmail.com ${ }^{4}$
}

\begin{abstract}
Abstrak
Pesantren di Indonesia merupakan salah satu lembaga pendidikan dan dakwah yang terus mengalami kemajuan yang sangat pesat dalam satu dasawarsa terakhir. Pesantren yang mengandalkan operasionalnya dari SPP santri dan koperasi juga terkena dampak karena sangat bergantung pada kehadiran dan daya beli santri, termasuk Pondok Pesantren Al Fatih, bagaimana dapat beradaptasi di tengah gejolak pandemi dan bisa menentukan sikap untuk memandirikan pondok pesantren. Tujuan utama dari kegiatan pengabdian pada masyarakat ini adalah lebih memotivasi dan meningkatkan kemandirian para santri dalam situasi pandemi. Pada tahap awal kegiatan dilakukan berbagai pendekatan melalui survei lokasi, wawancara penggalian informasi dengan para pengurus pondok pesantren agar dapat diketahui apa permasalahan yang dihadapi. Program pengabdian dilakukan dengan pemberian motivasi kewirausahaan dengan tujuan untuk mendongkrak kembali turunnya motivasi untuk berwirausaha karena adanya pandemi. Materi tentang dasar-dasar manajemen dan akuntansi ditambahkan agar para santri mengetahui dan memahami perlunya manajemen dalam bisnis skala kecil sekalipun. Setelah program terlaksana, tampak adanya peningkatan motivasi dari para santri untuk kembali menekuni usaha yang sempat terbengkalai selama pandemi. Mereka juga mulai memahami perlunya manajemen dalam pengelolaan usahanya.
\end{abstract}

Kata kunci: kemandirian, pondok pesantren, kewirausahaan

\section{Abstract}

Pesantren in Indonesia is one of the educational and da'wah institutions that continues to progress very rapidly in the last decade. Islamic boarding schools that rely on their operations from student tuition fees and cooperatives are also affected because they are very dependent on the presence and purchasing power of students, including the Al Fatih Islamic Boarding School, how to adapt in the midst of the pandemic turmoil and be able to determine the attitude to become independent Islamic boarding schools. The main purpose of this community service activity is to motivate and increase the independence of the students in a pandemic situation. In the early stages of the activity, various approaches were taken through site surveys, information gathering interviews with the administrators of Islamic boarding schools in order to find out what the problems were. The service program is carried out by providing entrepreneurial motivation with the aim of boosting the decline in motivation for entrepreneurship due to the pandemic. Materials on the basics of management and accounting are added so that students know and understand the need for management even in small scale businesses. After the program was implemented, there was an increase in the motivation of the students to return to their businesses that had been neglected during the pandemic. They also begin to understand the need for management in managing their business

Keywords: independence, islamic boarding school, entrepreneur

Copyright (c) 2021 Nur Kholis, Ida Ayu Kade Rachmawati K, Hestin Muthmainah, Rosita $\triangle$ Corresponding author

Address : Sekolah Tinggi Ilmu Ekonomi Surakarta

Email : nukonurkholis1988@gmail.com

DOI : https://doi.org/10.31004/abdidas.v2i4.366

ISSN 2721- 9224 (Media Cetak)

ISSN 2721- 9216 (Media Online) 
810 Kemandirian Ekonomi Santri Pondok Pesantren Menghadapi Masa Pandemi- Nur Kholis, Ida Ayu Kade Rachmawati K, Hestin Muthmainah, Rosita

DOI: https://doi.org/10.31004/abdidas.v2i4.366

\section{PENDAHULUAN}

Pesantren di Indonesia merupakan salah satu lembaga pendidikan dan dakwah yang terus mengalami kemajuan yang sangat pesat dalam satu dasawarsa terakhir. Menurut catatan Dirjen Pendidikan Islam Departemen Agama, bahwa pada tahun 2016 tercatat terdapat 28.194 pesantren dengan jumlah santri 4.290.626, yang sebelumnya di tahun 2005 tercatat 14.798 dengan jumlah santri 3.464.334. Abdun (2020) menyatakan bahwa selama ini para santri dididik dan dibekali berbagai ilmu dan pengetahuan, tidak hanya fokus pada keagamaan tetapi juga ilmu dan pengetahuan secara umum. Deputi Pengembangan Pemuda Kementerian Pemuda dan Olahraga RI, Asrorun Niam Sholeh dalam agenda Pesantrenpreneur di Pondok Pesantren Nashrul Ummah, Mejobo, Kudus (30/12), menyatakan bahwa "Pesantren tidak saja mendidik para santri untuk mengkaji literasi keagamaan, tetapi saatnya pesantren yang merupakan basis dan model pendidikan khas Indonesia tertua untuk mengembangkan minat dan bakat para pemuda santri melalui wirausaha (Jurnal entrepeneur, 2021).

Nadzir (2015) dalam Jurnal Economica menyatakan bahwa Pesantren sebagai lembaga yang hidup di tengah-tengah masyarakat mempunyai peran yang sangat penting, baik yang terkait dengan persoalan keagamaan (moral force) maupun yang terkait dengan sosial kemasyarakatan. Upaya yang dapat dilakukan oleh pesantren di antaranya adalah mempersiapkan para santri dengan memberikan bekal keahlian-keahlian tertentu, menanamkan jiwa wirausaha pada santri, dengan memberikan wawasan sejak dini, perlu adanya pemahaman dari kalangan pesantren bahwa persoalan sosial di masyarakat juga merupakan tanggung jawab pesantren sebagai bagian dari hablum min al anas dan dakwah bil hal (Antonio, 2001).

Demikian pula, bagi para santri di Pondok Pesantren Al Fatih. Selain menempuh pendidikan di berbagai jenjang pendidikan formal sesuai dengan tingkatannya, mereka juga dibekali dengan berbagai keterampilan agar dapat memupuk jiwa kemandirian sejak dini. Selama ini, Pondok Pesantren Al Fatih menanamkan pengertian dan pemahaman agar dalam operasional pondok tidak hanya bergantung pada donatur, terlebih pada pembayaran dari para santrinya karena para santri tersebut sebagian besar berasal dari keluarga yang kurang mampu.

Pondok Pesantren Al Fatih bukanlah pondok pesantren pertama yang dikenal dan menjadi mitra dalam kegiatan pengabdian pada masyarakat oleh tim pengabdi dari STIE Surakarta. Sebelumnya Pondok Pesantren Al Amin yang terletak di Karanganyar pernah menjalin kerja sama sebagai mitra dengan kegiatan pemberdayaan koperasinya (Koppontren). Pondok Pesantren Ad-Dhuhaa yang terletak di wilayah Sukoharjo juga pernah menjadi mitra dalam pemberdayaan santrinya dalam kegiatan peningkatan nilai ekonomis dan marketing berbagai produk yang diproduksi para santrinya. Pondok Pesantren Imam Syuhodo yang terletak di wilayah Sukoharjo juga pernah menjadi mitra dalam kegiatan motivasi kewirausahaan bagi para guru dan pengurus pondok pesantren tersebut. 
811 Kemandirian Ekonomi Santri Pondok Pesantren Menghadapi Masa Pandemi- Nur Kholis, Ida Ayu Kade Rachmawati K, Hestin Muthmainah, Rosita

DOI: https://doi.org/10.31004/abdidas.v2i4.366

Dalam masa pandemi Covid-19 seperti saat ini yang sudah berjalan selama satu tahun, dan belum ada kepastian kapan akan berakhir. Tak dapat dielakkan bahwa kehidupan dalam berbagai bidang tidak dapat berjalan sebagaimana mestinya seperti saat sebelum pandemi. Pola kerja dan belajar banyak mengalami perubahan, dari yang sebelumnya bertatap muka secara fisik, hingga saat ini masih dibatasi dan dilakukan secara daring.

Dampak kesehatan dan ekonomi dari pandemi Covid-19 ini juga berpengaruh pada kemandirian dan perkembangan pondok pesantren. Banyak pesantren yang terpaksa harus memulangkan santrinya atau menunda kedatangan santri karena kebijakan PSBB. Pesantren yang mengandalkan operasionalnya dari SPP santri, dapur, kantin dan koperasi juga terkena dampak karena sangat bergantung pada kehadiran dan daya beli santri. Pesantren juga perlu mengelaborasi sumber-sumber pendapatan yang menjadi penunjang operasional pesantren di luar sumber pendanaan yang selama ini menjadi andalan, seperti SPP, dapur, kantin atau koperasi (Prajono, O.S \& Pranarka, 1996).

Menteri Keuangan Sri Mulyani Indrawati mengajak para santri dan pesantren untuk saling gotong royong membantu pemerintah dalam akselerasi pemulihan ekonomi nasional akibat pandemi Covid-19. Santri harus menjadi sumber inspirasi terhadap daya tahan dan daya mampu ekonomi untuk terus berkreasi di dalam cobaan Covid-19. Menteri Agama Fachrul Razi mengatakan bahwa Akselerasi Ekonomi Kerakyatan berbasis Pesantren dan Komunitas merupakan refleksi tanggung jawab bersama untuk mewujudkan kesejahteraan dan masa depan yang lebih baik bagi rakyat Indonesia (Prajono, O.S \& Pranarka, 1996).

Lantas, bagaimana Pondok Pesantren Al Fatih dapat beradaptasi di tengah gejolak pandemi dan bisa menentukan sikap untuk memandirikan pondok pesantren? Akan menjadi tantangan dan tugas yang berbeda yang harus dilakukan oleh tim pengabdi dari STIE Surakarta agar dapat berperan dalam mempertahankan bahkan meningkatkan kemandirian pondok pesantren melalui kemandirian ekonomi para santri di saat pandemi dengan tanpa menimbulkan kesan eksploitasi pada mereka.

\section{METODE}

Pada tahap awal kegiatan ini dilakukan pada tanggal 15 Februari 2021 dengan pendekatan melalui survei lokasi, wawancara penggalian informasi dengan para pengurus pondok pesantren agar dapat diketahui apa permasalahan yang dihadapi. Setelah diadakan diskusi oleh tim pengabdi bersama Lembaga Penelitian dan Pengabdian Masyarakat STIE Surakarta tentang bagaimana solusi yang bisa diberikan melalui berbagai kegiatan berikutnya.

Kegiatan pengabdian ini diputuskan akan dilakukan selama 2 hari yaitu tanggal 19 dan 20 Februari 2021. Adapun kegiatan yang direncanakan akan dilakukan adalah sebagai berikut :

\section{A. Hari Pertama (Tanggal 19 Februari 2021)}

1. Motivasi Kewirausahaan.

Kegiatan ini bertujuan untuk meningkatkan kembali motivasi para santri dalam 
812 Kemandirian Ekonomi Santri Pondok Pesantren Menghadapi Masa Pandemi- Nur Kholis, Ida Ayu Kade Rachmawati K, Hestin Muthmainah, Rosita

DOI: https://doi.org/10.31004/abdidas.v2i4.366

berwirausaha demi tercapainya kemandirian. Selama ini para santri sudah mempunyai keterampilan dan berproduksi dalam skala kecil produk susu kedelai berbagai rasa. Produk-produk tersebut selain digunakan untuk memenuhi kebutuhan internal pondok juga diperjual belikan di lingkungan terdekat ataupun masyarakat di sekitar pondok pesantren. Dengan adanya pandemi yang tentunya membatasi aktivitas para santri di luar pondok tentu menyulitkan bagi mereka untuk memasarkan produknya seperti saat sebelum pandemi dan adanya pembatasan kegiatan masyarakat.

\section{Produksi}

Terutama terkait proses produksi yang selama ini dalam skala kecil dan belum terkoordinasi dengan baik. Proses produksi tentu harus cermat mulai dari memperoleh bahan baku, proses pembuatan, dan pengemasan. Proses produksi yang efisien akan dapat menghasilkan produk yang bisa bersaing di pasaran.

3. Manajemen Sumber Daya Manusia Selama ini tidak semua santri yang ada di pondok pesantren dilibatkan untuk kegiatan produksi maupun pemasaran. Mereka yang terlibat terutama adalah para santri yang sudah duduk di jenjang SMA. Bagi para santri yang lain diperkenankan membantu dengan ketentuan tidak mengganggu aktivitas wajib lainnya. Sekecil apapun organisasinya, SDM yang dimiliki harus diatur sedemikian rupa sehingga masingmasing mempunyai tugas dan tanggung jawab. Dengan pengetahuan ini diharapkan dapat memupuk disiplin, dan tanggung jawab para santri.

B. Hari Kedua (Tanggal 20 Februari 2021)

1. Manajemen Keuangan dan Akuntansi Sederhana

Salah satu hal yang sering membuat kegagalan suatu bisnis adalah pengaturan keuangan yang kurang baik. Hal tersebut akan membuat kesalahan dalam menghitung ataupun menentukan biaya produksi yang dikeluarkan, harga yang terlalu tinggi ataupun rendah yang bisa menimbulkan kerugian. Selain itu, tidak adanya pencatatan yang jelas akan menyulitkan bila ingin mengetahui keuntungan yang diperoleh apalagi pengembangan usaha kedepannya.

2. Manajemen Pemasaran

Ujung tombak suatu bisnis adalah pemasaran. Pemasaran membuat produk dikenal dan digunakan oleh masyarakat/konsumen. Dengan adanya penjualan yang kontinu dan meningkat diharapkan bisa meningkatkan keuntungan serta usaha ataupun bisnis yang dirintis. Kondisi pandemi menuntut kita agar bisa lebih kreatif dan inovatif dalam memasarkan produk ditengah berbagai keterbatasan.

Setelah diadakan pendidikan dan pelatihan selama 2 hari yaitu tanggal 19 dan 20 Februari 2021, kegiatan dilanjutkan dengan pendampingan yang direncanakan selama 2 bulan yang terbagi 
813 Kemandirian Ekonomi Santri Pondok Pesantren Menghadapi Masa Pandemi- Nur Kholis, Ida Ayu Kade Rachmawati K, Hestin Muthmainah, Rosita

DOI: https://doi.org/10.31004/abdidas.v2i4.366

dalam 4 periode 3 mingguan. Adapun kegiatan pendampingan diatur sebagai berikut :

A. Periode pertama tanggal 12 Maret 2021

1. Pembentukan susunan organisasi;

2. Proses produksi yang efisien;

3. Packaging.

B. Periode kedua tanggal 26 Maret 2021

1. Perhitungan biaya produksi dan penentuan harga;

2. Penyusunan pencatatan keuangan dengan prinsip akuntansi sederhana;

3. Pemasaran online.

C. Periode ketiga pada tanggal 15 April 2021

1. Analisis keuntungan;

2. Penyusunan anggaran;

3. Mulai mengamati dan menyusun sasaran, dan target.

D. Periode keempat pada tanggal 29 dan 30 April 2021

1. Perluas media dan jangkauan pemasaran;

2. Analisis SWOT;

3. Rencana pengembangan unit bisnis.

Setelah dilaksanakan pendampingan selama

2 bulan selanjutnya akan ada evaluasi dari tim pengabdian untuk melihat progres produksi dan penjualan 3 bulan serta memonitor catatan keuangan setelah dilaksanakan pelatihan dan pendampingan yang nantinya akan dijadikan bahan masukan tim untuk memberikan materi lanjutan.

Tim pengabdi dari STIE Surakarta terdiri dari 4 dosen, sebagai berikut :
Tabel 1. Tim Pengabdi dari STIE Surakarta

\begin{tabular}{|l|l|l|l|}
\hline No & \multicolumn{1}{|c|}{ Nama } & \multicolumn{1}{|c|}{ Bidang } & $\begin{array}{l}\text { Tanggung- } \\
\text { Jawab Kegiatan }\end{array}$ \\
\hline 1 & $\begin{array}{l}\text { Nur Kholis, } \\
\text { S.E., Msc }\end{array}$ & Akuntansi & $\begin{array}{l}\text { Manajemen } \\
\text { Keuangan dan } \\
\text { Akuntansi }\end{array}$ \\
\hline 2 & $\begin{array}{l}\text { Ida Ayu } \\
\text { Kade } \\
\text { Rachmawati } \\
\text { K, S.E., M.M }\end{array}$ & Manajemen & $\begin{array}{l}\text { Manajemen } \\
\text { Pemasaran dan } \\
\text { Manajemen } \\
\text { Produksi }\end{array}$ \\
\hline 3 & $\begin{array}{l}\text { Hestin M, } \\
\text { S.E., M.M. }\end{array}$ & Manajemen & $\begin{array}{l}\text { Kewirausahaan } \\
\text { dan Manajemen } \\
\text { SDM }\end{array}$ \\
\hline 4 & $\begin{array}{l}\text { Rosita, S.E., } \\
\text { M.M., CA }\end{array}$ & Akuntansi & $\begin{array}{l}\text { Akuntansi Biaya } \\
\text { dan Anggaran }\end{array}$ \\
\hline
\end{tabular}

\section{HASIL DAN PEMBAHASAN}

Tujuan utama dari kegiatan pengabdian pada masyarakat ini adalah lebih memotivasi dan meningkatkan kemandirian para santri dalam situasi pandemi. Dengan beberapa kegiatan yang sudah dilaksanakan, sudah ada beberapa kemajuan yang sudah dirasakan. Motivasi kewirausahaan yang diadakan pada hari pertama sebagai pembuka kegiatan. Motivasi ini diberikan dengan tujuan agar para santri tetap mempunyai motivasi tinggi dengan berbagai upaya aktivitas kemandirian yang sudah dimiliki di tengah masa pandemi yang banyak memberikan dampak negatif bagi para pelaku ekonomi. Dalam mengelola suatu usaha ataupun bisnis, tak dapat dipungkiri bahwa akan selalu ada hambatanhambatan yang harus dihadapi dan dicari solusi terbaik agar tidak menghalangi pencapaian tujuan yang diinginkan. Kuncinya adalah selalu mengasah kreativitas dan berinovasi agar dapat beradaptasi di setiap perubahan maupun keadaan. Sebagaimana halnya iman seseorang yang terkadang naik dan turun karena berbagai kondisi yang melatarbelakanginya, demikian pula halnya 
814 Kemandirian Ekonomi Santri Pondok Pesantren Menghadapi Masa Pandemi- Nur Kholis, Ida Ayu Kade Rachmawati K, Hestin Muthmainah, Rosita

DOI: https://doi.org/10.31004/abdidas.v2i4.366

motivasi. Saat target tercapai seringkali akan dapat meningkatkan motivasi, demikian pula sebaliknya. Pandemi memang telah banyak membawa dampak negatif terutama dalam bidang kesehatan, pendidikan, dan ekonomi. Di sisi lain, bagi mereka yang terus mengasah kemampuan diri, berpikir kreatif dan inovatif, selalu berusaha bagaimana agar hambatan bisa menjadi peluang. Motivasi bisa ditingkatkan dari dalam diri seseorang tetapi tak jarang juga bisa diberikan dari orang lain dan lingkungannya.

Sebagian besar santri yang dilibatkan sebagai peserta dalam kegiatan ini adalah mereka yang berada di tingkat sekolah menengah atas. Harapannya, pemudalah yang akan dapat menggerakkan pemberdayaan ini, yang akan dapat memotivasi diriya maupun santri yang lain. Harapan tersebut tidak sia-sia, terbukti bahwa selama kegiatan ini berlangsung, mereka sangat antusias mengikuti setiap aktivitas baik materi maupun pendampingannya. Mereka juga bisa menularkan semangat/motivasi tersebut kepada para santri yang lain dengan melibatkannya dalam kegiatan-kegiatan yang diarahkan saat pendampingan. Pemberian motivasi ibarat membangunkan mereka yang selama ini termenung dalam menghadapi perubahan yang terjadi karena pandemi.

Masih di hari yang sama dengan semangat yang berbeda, lebih tinggi tentunya, diberikan materi ataupun pengetahuan mengenai manajemen produksi. Materi diberikan secara sederhana agar bisa lebih mudah dimengerti dan bisa diaplikasikan/dipraktikkan. Selama ini para santri sudah mempunyai rintisan usaha produksi susu kedelai. Momen pandemi ini bisa dilihat sebagai peluang karena salah satu bidang yang masih menjadi perhatian tinggi di masyarakat adalah kesehatan. Masyarakat masih memburu berbagai produk kesehatan agar bisa terhindar dari terpapar virus Covid-19 maupun penyakit lainya. Susu kedelai hingga kini masih seringkali dipandang sebelah mata dibandingkan dengan produk olahan susu dari hewani seperti sapi, kambing, maupun hewan lainnya. Inilah saatnya bagi produk susu kedelai agar bisa "unjuk diri” sebagai salah satu produk yang dapat menjaga kesehatan dan terjangkau. Tentu saja tidak hanya dengan produksi seadanya tanpa upaya pengelolaan yang memadai.

Dalam memproduksi susu kedelai dengan kapasitas terbatas, para santri hanya mengandalkan pasokan bahan baku, yaitu kedelai yang diperoleh dari pasar terdekat. Bahan yang lain pun seperti gula pasir dan perasa juga diperoleh di pasar bahkan terkadang di warung terdekat dari pondok. Dari segi harga, terutama untuk kedelai biasanya didapatkan harga yang lebih tinggi karena pembelian yang dilakukan dalam jumlah yang sedikit dan tidak kontinu. Belum lagi, bila harga kedelai mengalami peningkatan, karena kedelai juga merupakan bahan baku bagi pembuatan tempe dan tahu. Selama ini, perasa yang digunakan adalah dengan menambahkan sirup dengan rasa yang diinginkan seperti stroberi maupun melon.

Sebagai produk yang mendukung kesehatan, diharapkan proses produksinya pun juga baik dan higienis. Untuk membuat susu kedelai ini, sebaiknya menggunakan takaran yang 
815 Kemandirian Ekonomi Santri Pondok Pesantren Menghadapi Masa Pandemi- Nur Kholis, Ida Ayu Kade Rachmawati K, Hestin Muthmainah, Rosita

DOI: https://doi.org/10.31004/abdidas.v2i4.366

pas dan tidak berubah-ubah ataupun hanya menggunakan perasaan saja. Formula/ racikan yang tepat tentu akan menghasilkan produk yang baik. Bila selama ini sudah mempunyai resep yang paten, dalam arti bisa dipercaya bahwa susu kedelai yang dihasilkan bisa diterima oleh selera konsumen, maka hendaknya resep tersebut dipegang teguh saat proses produksinya. Sebaliknya, bila belum mempunyai resep/takaran yang tepat, tentu harus dilakukan uji coba yang terkadang harus melalui upaya trial dan error beberapa kali.

Agar pengukuran lebih tepat maka tim pengabdi memberikan bantuan berupa alat penimbang digital yang portabel dengan kapasitas maksimal $5 \mathrm{~kg}$. Untuk alat pencampuran ataupun penghalusan biji kedelai (blender), para santri sudah memilikinya. Saran yang diberikan oleh tim pengabdi adalah mengganti perasa yang awalnya menggunakan sirup dengan berbagai rasa dengan buah-buahan yang lebih alami dan tentu menyehatkan. Tentu saja, perlu penyesuaian terhadap resep/ racikan yang selama ini digunakan.

Pengemasan yang selama ini dilakukan adalah menggunakan kemasan plasik tanpa merek/ label yang mendukung. Untuk itu, agar bisa mendukung kegiatan penjualan, untuk langkah awal, kemasan tersebut diberikan label merek agar mempunyai identitas yang jelas. Dalam label tersebut, selain merek juga disertakan penjelasan mengenai identitas pembuat dan nomor HP santri, dengan tujuan agar bila ada permintaan/pemesanan dari pihak luar/konsumen, tidak kesulitan untuk menghubungi. Disertakan juga keterangan bahwa produk tersebut menggunakan perasa alami.
Sebagaimana yang diberikan dalam materi berikutnya tentang manajemen SDM, maka para santri yang terlibat juga membentuk struktur organisasi atau sederhananya kepengurusan. Setidaknya masing-masing kegiatan ada penanggungjawabnya seperti produksi, keuangan, dan pemasaran. Masing-masing bagian diberikan tugas/tanggungjawab untuk memaksimalkan sumber daya yang dimiliki. Kegiatan produksi diatur sedemikian rupa mulai dari pengadaan bahan baku hingga produk susu kedelai sudah dikemas dan siap dijual. Kegiatan pemasaran bertanggungjawab atas distribusi susu kedelai hingga sampai ke tangan konsumen. Ada beberapa lokasi yang menjadi sasaran pemasaran seperti beberapa penjual kuliner yang berada tidak juga dari pondok maupun secara online. Bagian keuangan mengatur anggaran biaya yang diperlukan maupun pencatatan keuangan secara sedehana. Dengan adanya pembagian tugas dan tanggungjawab tersebut, masing-masing bagian/tim bisa bekerja dengan lebih terarah dan disiplin.

Banyak bukti yang memperlihatkan bahwa pengelolaan keuangan adalah faktor yang sangat penting dan riskan dalam menjalankan suatu bisnis maupun perusahaan. Kesuksesan dan kegagalan usaha sangat dipengaruhi oleh baik tidaknya pengaturan keuangan. Pengaturan sekaligus pencatatan keuangan yang baik akan sangat membantu dalam banyak hal, setidaknya penentuan harga pokok yang jelas, penentuan harga yang memadai/kompetitif, sekaligus bisa mengetahui keuntungan (maupun kerugian) yang dialami. Sedemikian penting keberadaan 
816 Kemandirian Ekonomi Santri Pondok Pesantren Menghadapi Masa Pandemi- Nur Kholis, Ida Ayu Kade Rachmawati K, Hestin Muthmainah, Rosita

DOI: https://doi.org/10.31004/abdidas.v2i4.366

pencatatan keuangan membuat para pelaku usaha tidak lagi menyepelekan keberadaannya dan menugaskan secara khusus orang-orang yang memang memiliki kemampuan dalam bidang tersebut. Bagi para santri yang duduk di bangku SMA terutama bagi mereka yang mengambil jurusan IPS, pengetahuan mengenai penyusunan laporan keuangan secara sederhana tentu saja bukan hal yang asing, sehingga tim pengabdi hanya perlu mengingatkan agar pencatatan tersebut selalu dilakukan dengan beberapa arahan mengenai alur maupun sarana pencatatan yang bisa dilakukan, setidaknya secara manual.

Ujung tombak bagi perusahaan maupun bisnis untuk memperoleh keuntungan adalah bagian penjualan atau marketing. Untuk itulah segenap kegiatan di bidang ini mendapat perhatian lebih. Salah satu startegi pemasaran yang bisa digunakan adalah STP (Segmenting, Targeting, dan Positioning). Sasaran yang tepat, pengelolaan yang benar, memenangkan persaingan, meraih keuntungan, menguasai pasar, merupakan sebagian dari sekian banyak manfaat yang akan didapatkan dengan menyusun dan menerapkan strategi pemasaran. Strategi pemasaran STP ini berarti proses mengategorikan, membidik pasar yang diinginkan, lalu memposisikan pemasaran bisnis dibandingkan pesaing.

$$
\text { Segmenting merupakan proses }
$$

mengategorikan, mengklasifikasikan, menggolongkan semua target potensial produk yang akan dipasarkan. Syarat segmentasi yang efektif adalah measurable (terukur), substansial (banyak), accessible (dapat diakses), differentiable (dapat dibedakan), dan actionable (dapat dilayani).
Selanjutnya adalah mengevaluasi berbagai segmen tersebut untuk memutuskan segmen mana yang akan menjadi target market. Positioning merupakan proses mengembangkan strategi pemasaran yang bertujuan untuk mempengaruhi bagaimana sebuah segmen pasar tertentu memandang sebuah barang atau jasa dibandingkan dengan kompetisi atau pesaing. Penentuan posisi pasar menunjukkan bagaimana suatu produk dapat dibedakan dari produk pesaingnya (Jurnal Entrepreneur, 2021).

Produk susu kedelai bisa menyasar ke setiap kalangan dari anak-anak, remaja, maupun orang tua. Susu kedelai biasanya dipilih karena berasal dari nabati bukan hewani yang bisa menimbulkan dampak alergi. Dari sisi harga, juga terjangkau dari kalangan bawah, menengah maupun atas. Untuk lebih memfokuskan sasaran maka produk susu kedelai diperuntukkan bagi mereka yang alergi terhadap susu hewani, konsentrasi terhadap kesehatan, dan harga terjangkau. Masyarakat seringkali khawatir mengkonsumsi susu karena takut menjadi gemuk, padahal lemak yang terkandung dalam susu lebih baik dibandingkan dengan produk makanan lain seperti gorengan yang ternyata lebih banyak dikonsumsi. Terlebih produk susu kedelai, tentu lemaknya lebih renah, dan sehat ditambah dengan perasa alami dari sari buah.

Setelah mendapatkan materi secara teori, sesuai dengan rencana sebelumnya, maka akan diadakan kegiatan pendampingan. Tahap pertama pendampingan meliputi berbagai kegiatan, yaitu pembentukan struktur organisasi, agar jelas penanggungjawab setiap kegiatan usaha yang 
817 Kemandirian Ekonomi Santri Pondok Pesantren Menghadapi Masa Pandemi- Nur Kholis, Ida Ayu Kade Rachmawati K, Hestin Muthmainah, Rosita

DOI: https://doi.org/10.31004/abdidas.v2i4.366

dijalankan. Unit kegiatan usaha susu kedelai ini telah membentuk struktur organisasinya sebagai berikut :

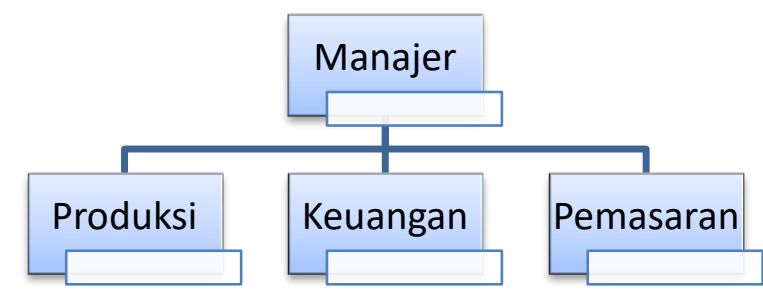

Gambar 1. Struktur Organsiasi

Langkah berikutnya adalah proses produksi yang efisien. Bahan baku terutama kedelai disarankan unuk mencari supplier yang bisa memberikan kedelai dengan kualitas baik secara kontinu dengan harga yang terjangkau. Supplier yang dipilih adalah penjual kedelai di Pasar Gede Solo diputuskan untuk membeli kedelai dalam jumlah memadai dalam jangka waktu yang kontinu tiga kali dalam seminggu karena pengolahannya menjadi susu memerlukan waktu yang cukup lama. Kedelai harus dicuci bersih, kemudian direndam kurang lebih selama 8 jam, kemudian dicuci kembali dan dibuang kulitnya. Proses berikutnya kedelai dihaluskan menggunakan blender, direbus, disaring, baru kemudian dikemas.

Pengemasan yang dilakukan masih menggunakan kemasan plastik dengan kapasitas $125 \mathrm{ml}$ dengan tambahan label merek yang sudah dibuatkan oleh tim pengabdi. Ke depannya direncanakan untuk menggunakan kemasan botol dengan kapasitas sekitar $200 \mathrm{ml}$ agar lebih menarik dan bisa disimpan rapi di lemari pendingin.
Pendampingan sesi kedua juga terdiri dari beberapa kegiatan. Perhitungan biaya produksi agar dapat ditentukan harga jualnya. Adapun perhitungan harga pokoknya adalah sebagai berikut:

Tabel 2. Perhitungan Harga Pokok

\begin{tabular}{|c|c|c|c|c|}
\hline \multicolumn{3}{|c|}{ Bahan } & Harga & Total \\
\hline \multicolumn{2}{|c|}{ Uk } & Nama & @ & $\mathbf{R p}$ \\
\hline 1 & $\mathrm{~kg}$ & Kedelai & 10.000 & 10.000 \\
\hline 0,5 & $\mathrm{~kg}$ & Gula pasir & 13.000 & 6.500 \\
\hline 4 & bks & Vanili & 200 & 800 \\
\hline 4 & sdt & Garam & 125 & 500 \\
\hline 1,5 & $\begin{array}{r}\text { lite } \\
r\end{array}$ & Air mineral & 475 & 713 \\
\hline 0,25 & $\mathrm{~kg}$ & buah & 15.000 & 3.750 \\
\hline 25 & pcs & $\begin{array}{l}\text { Kemasan } \\
\text { plastik }\end{array}$ & 100 & 2.500 \\
\hline 1 & & Gas & 1.800 & 1.800 \\
\hline 4 & $\begin{array}{r}\text { ora } \\
\text { ng }\end{array}$ & $\begin{array}{l}\text { Tenaga } \\
\text { kerja }\end{array}$ & 1.000 & 4.000 \\
\hline 0,25 & $\begin{array}{r}\text { lite } \\
\mathrm{r}\end{array}$ & $\begin{array}{l}\text { Transporta } \\
\text { si }\end{array}$ & 7.650 & 1.913 \\
\hline \multicolumn{4}{|c|}{ Total Harga Pokok Produksi } & 32.475 \\
\hline
\end{tabular}

Dari total biaya tersebut, bisa menghasilkan susu kedelai sebanyak 25 kemasan. Sehingga per kemasannya sebesar Rp 1.300,- bila harga jual pada umumnya $\mathrm{Rp} 2.000$,- per kemasan dikurangi bagi hasil sebesar 10\%, maka harga jualnya sebesar Rp 1.800,-

Aktivitas berikutnya adalah penyusunan pencatatan keuangan dengan prinsip akuntansi secara sederhana. Pencatatan ini perlu dilakukan guna mendukung pengelolaan usaha yang baik dan transparan. Dengan adanya pencatatan tersebut, bisa dibuat laporan keuangan hingga dapat diketahui perkembangan usaha dari waktu ke waktu. Aktivitas pendukung berikutnya adalah upaya melakukan pemasaran secara online. Untuk 
818 Kemandirian Ekonomi Santri Pondok Pesantren Menghadapi Masa Pandemi- Nur Kholis, Ida Ayu Kade Rachmawati K, Hestin Muthmainah, Rosita

DOI: https://doi.org/10.31004/abdidas.v2i4.366

langkah awal bisa menggunakan media sosial yang biasa digunakan oleh para santri seperti Instagram, WhatsApp, dan Facebook. Direncanakan untuk dilanjutkan dengan menggunakan Google My Business.

Sesi pendampingan berikutnya terdiri dari tiga kegiatan. Dimulai dari analisis keuntungan. Dengan harga jual yang telah ditentukan sebesar Rp 1.800,- per kemasan tersebut diperoleh keuntungan sebesar Rp. 500 per kemasan. Ilustrasi tersebut menggunakan asumsi bila menggunakan bahan baku kedelai sebanyak $1 \mathrm{~kg}$. Bila dalam sehari mampu berproduksi setidaknya $5 \mathrm{~kg}$, maka keuntungan yang diperoleh adalah sebesar: Rp 500,- x 25 kemasan x $5=$ Rp 62.500,-. Bila dalam sebulan maka keuntungan yang diperoleh sebesar: Rp 62.500,- x 30 hari = Rp 1.875.000,-.

Untuk kegiatan berikutnya adalah penyusunan anggaran. Terutama bila sudah mulai menggunakan media sosial sebagai sarana pemasaran serta pengembangan usaha lainnya seperti mengemas dalam botol serta pemberian label merek yang menarik. Bila terjadi perluasan area pemasaran, tentunya akan mempengaruhi kapasitas produksi yang harus diperhitungkan secara cermat, agar keuntungan yang diperoleh bisa diproyeksikan sebelumnya.

Mulai mengamati dan menyusun sasaran, dan target. Permintaan akan produk yang mendukung kesehatan meningkat dalam kondisi pandemi yang masih belum berakhir. Perluasan media dan jangkauan pemasaran dengan memberikan nilai lebih pada produk melalui kemasan botol yang lebih menarik, diharapkan dapat meningkatkan permintaan susu kedelai produksi para santri. Sasaran yang dituju adalah konsumen segala umur. Targetnya adalah mereka yang peduli pada kesehatan dan mengalami kendala bila mengkonsumsi susu dari sumber hewani.

Pada tahap berikutnya, dilakukan berbagai aktivitas seperti memperluas media dan jangkauan pemasaran, melakukan analisis SWOT, serta merencanakan pengembangan unit bisnis. Pembuatan akun Google My Business mulai dirintis, para santripun mulai diperkenalkan dan didampingi dalam penggunaan awalnya. Untuk membuat modifikasi tampilan maupun variasi konten, diserahkan pada kreatifitas para santri. Disamping itu, dilakukan juga evaluasi atas apa yang sudah dilakukan sebelumnya agar ada gambaran sejauh mana keberhasilan yang dapat dicapai, apakah kendala atau hambatan yang dihadapi, kemungkinan peluang serta ancaman di masa yang akan datang.

Dengan adanya analisis tersebut, diharapkan dapat digunakan sebagai pedoman dalam menyusun rencana pengembangan berikutnya.

Dokumentasi yang dilakukan mulai dari pembukaan, penyampaian materi dan penutup.

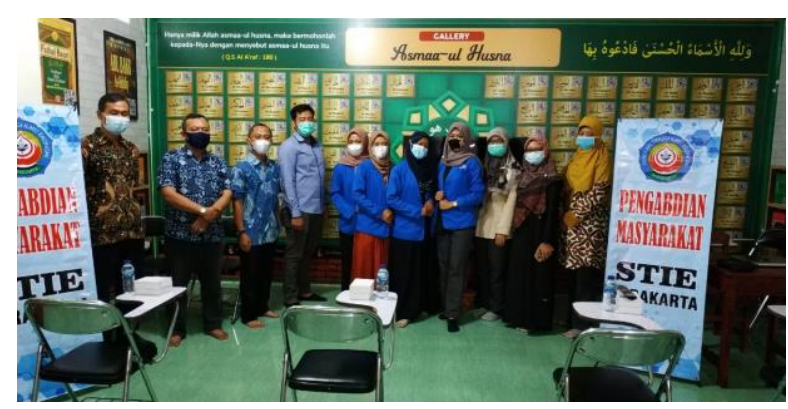

Gambar 2. Pembukaan Acara 


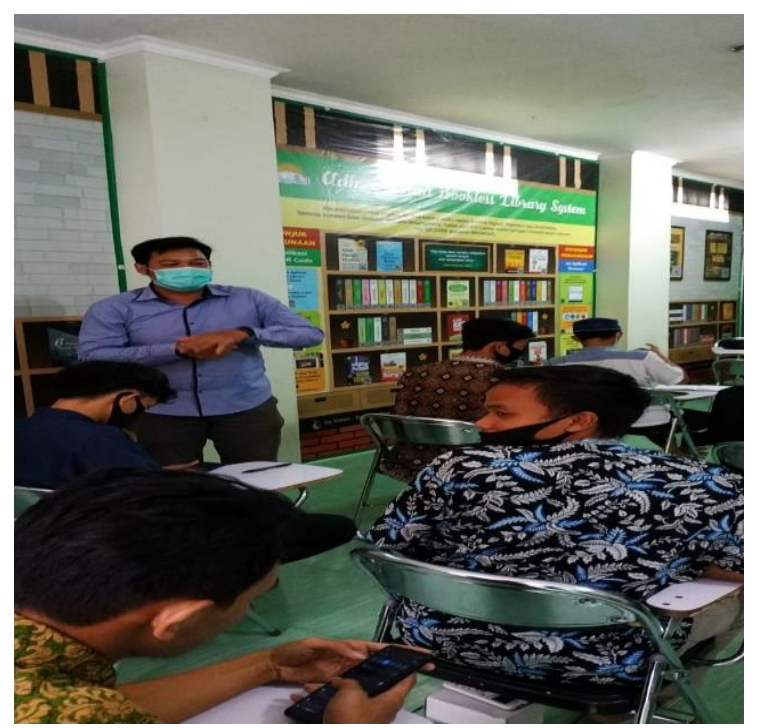

Gambar 3. Penyampaian Materi Akuntansi dan Anggaran

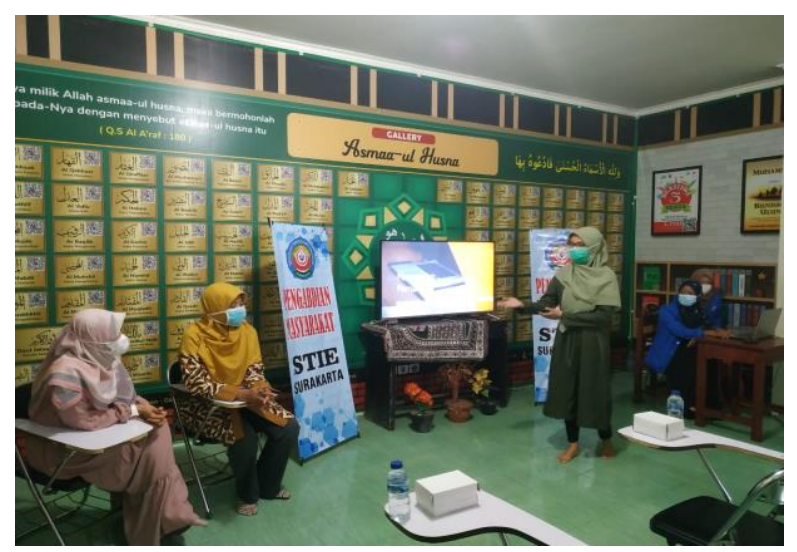

Gambar 4. Penyampaian Materi tentang

Manajemen Pemasaran dan Kewirausaan

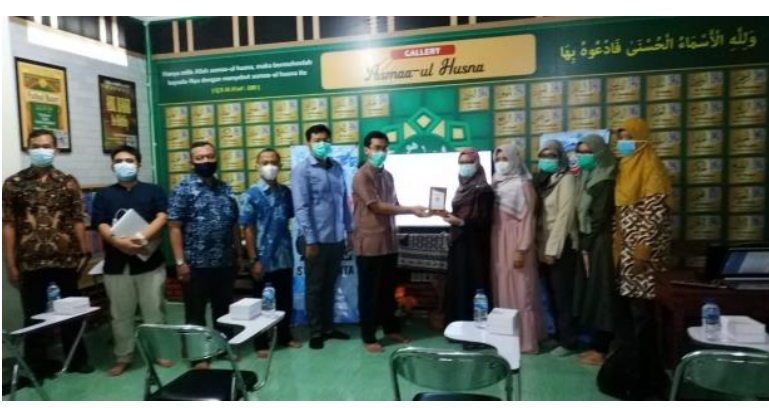

Gambar 5. Acara Penutupan

Setelah program terlaksana, tampak adanya peningkatan motivasi dari para santri untuk kembali menekuni usaha yang sempat terbengkalai selama pandemi. Mereka juga mulai memahami perlunya manajemen dalam pengelolaan usahanya. Sedikit demi sedikit mulai dilakukan pengelolaan seperti yang sudah diarahkan oleh tim pengabdi, mulai dari pembentukan tim kerja/manajemen secara sederhana, pembuatan produk yang terstandar, pengemasan yang lebih menarik dan informatif, pencatatan keuangan sederhana seperti arus kas, pemasaran online dimulai dari media sosial yang digunakan oleh para santri hingga pembentukan akun Google My Business, hingga perencanaan pengembangan usaha di antaranya yoghurt maupun produk lain yang berasal dari susu kedelai.

\section{SIMPULAN}

Mitra yang digandeng adalah salah satu pondok pesantren yang letaknya tidak terlalu jauh dari STIE Surakarta, yaitu Pondok Pesantren Al Fatih. Para santri sebelumnya sudah mempunyai unit usaha mandiri yaitu pembuatan susu kedelai yang belum dikelola dengan baik, usaha tersebut juga tersendat karena adanya dampak dari pandemi Covid-19.

Program pengabdian dilakukan dengan pemberian motivasi kewirausahaan dengan tujuan untuk mendongkrak kembali turunnya motivasi untuk berwirausaha karena adanya pandemi. Materi tentang dasar-dasar manajemen dan akuntansi ditambahkan agar para santri mengetahui dan memahami perlunya manajemen dalam bisnis skala kecil sekalipun.

Setelah program terlaksana, tampak adanya peningkatan motivasi dari para santri untuk kembali menekuni usaha yang sempat terbengkalai selama pandemi. Mereka juga mulai 
820 Kemandirian Ekonomi Santri Pondok Pesantren Menghadapi Masa Pandemi- Nur Kholis, Ida Ayu Kade Rachmawati K, Hestin Muthmainah, Rosita

DOI: https://doi.org/10.31004/abdidas.v2i4.366

memahami perlunya manajemen dalam pengelolaan usahanya. Sedikit demi sedikit, mulai dilakukan pengelolaan seperti yang sudah diarahkan oleh tim pengabdi, mulai dari pembentukan tim kerja/manajemen secara sederhana, pembuatan produk yang terstandar, pengemasan yang lebih menarik dan informatif, pencatatan keuangan sederhana seperti arus kas, pemasaran online dimulai dari media sosial yang digunakan oleh para santri hingga pembentukan akun Google My Business, hingga perencanaan pengembangan usaha di antaranya yoghurt maupun produk lain yang berasal dari susu kedelai.

Diharapkan kegiatan pengabdian pada masyarakat ini bisa memberikan motivasi dan meningkatkan kemandiriannya secara ekonomis. Dengan adanya pengalaman tersebut, mereka juga diharapkan dapat menularkannya pada para santri yang lain pada jenjang yang lebih rendah sekaligus memupuk kemandirian bilamana sudah lepas/lulus dari pondok pesantren tersebut.

\section{UCAPAN TERIMA KASIH}

Terima kasih kepada Tim Pengabdi dan Pengelola Pondok Pesantren Al Fatih yang memberikan kesempatan kepada kami untuk berbagi ilmu dan sharing pengalaman.

\section{DAFTAR PUSTAKA}

Abdun, M. N. (2020). Satri, Pesantren dan Kemandirian https://alif.id/read/muhammad-abdunnasir/santri-pesantren-dan-kemandirianekonomi-b225629p/

Antonio, M. S. (2001). Bank Syari'ah dari Teori ke Paraktek. Gema Insani.
Jurnal Entrepreneur. Implementasi Strategi Pemasaran STP pada Bisnis Online. (n.d.). Retrieved July 15, 2021, from https://www.jurnal.id/id/blog/apa-itu-stpsegmenting-targeting-positioning-contohstp-analisis-stp-adalah/

Nadzir, M. (2015). Membangun Pemberdayaan Ekonomi di Pesantren. Economica: Jurnal Ekonomi Islam, 6(1), 37-56.

Prajono, O.S, Pranarka, A. M. . (1996). Pemberdayaan: Konsep, Kebijakan, dan Implementasi. CSIS. 